\title{
Non-haemorrhagic causes of obstetrical intensive care unit admissions in tertiary care setting
}

\author{
Preet Kamal, Surinder Kaur*, Harleen Kaur, Madhu Nagpal
}

Department of Obstetrics and Gynecology, Sri Guru Ram Das University of Health Sciences, Amritsar, Punjab, India

Received: 07 February 2020

Accepted: 25 February 2020

*Correspondence:

Dr. Surinder Kaur,

E-mail: drsurinderkaur@yahoo.in

Copyright: (C) the author(s), publisher and licensee Medip Academy. This is an open-access article distributed under the terms of the Creative Commons Attribution Non-Commercial License, which permits unrestricted non-commercial use, distribution, and reproduction in any medium, provided the original work is properly cited.

\begin{abstract}
Background: Management of critically ill obstetric patients involve intensive monitoring in intensive care unit. In present scenario there are significant number of obstetric patients with sepsis, tropical diseases and medical illness that require ICU care. The aim of this study was to evaluate in more detail the non-haemorrhagic causes of obstetric ICU admissions and to identify and adopt high risk strategies as prime learning objective.

Methods: It is a prospective ongoing study conducted in 50 patients in SGRDUHS, Amritsar from December 2016 to October 2019, who were admitted in obstetric ICU, out of them 30 cases were attributed to non-haemorrhagic obstetric causes. All demographic parameters along with gestational age, diagnosis on admission, intervention done prior to shift to ICU and details of treatment given in ICU were evaluated. Patient outcome, review of mortality and area of improvement were also noted.

Results: Majority of the patient $(70.1 \%)$ were admitted in $3^{\text {rd }}$ trimester. Obstetric sepsis (13.33\%), infective diseases $(16.66 \%)$, tropical conditions $(16.66 \%)$, medical disorders $(26.66 \%)$ and hypertensive disorders $(26.66 \%)$ were the major causes of admission to obstetric ICU. There were $33.3 \%$ mortalities observed in present study and $40 \%$ were due to respiratory failure. In ICU mechanical ventilation was done in $63.3 \%$ cases and blood products were given in $33.3 \%$ of patients.

Conclusions: A multidisciplinary approach is ideal to handle non-haemorrhagic situations especially related to medical disorders and tropical diseases. Review of the ICU admissions and periodic audit can improve management of morbidities as well as reduce maternal mortalities.
\end{abstract}

Keywords: Critical care, Intensive care unit, Medial disorders, Obstetrics, Risk reduction strategies

\section{INTRODUCTION}

Pregnancy is a stressful physiological condition for a woman. Normal antenatal and postnatal period rarely requires intensive monitoring but sometimes pregnancy unmasks or can worsen the underlying co-morbidities or can be superimposed by obstetrical or non-obstetrical complications leading to need of critical care. In developed countries, the average incidence of ICU/HDU admissions is 2-4/1000 deliveries while in developing countries the incidence ranges from $2-12.5 / 1000 .^{1}$
Obstetric ICU patients have lower mortality rate as compared to general ICU female population (2-3\% versus $20 \%)^{2}$ This is because the patients are young and comorbidities are rare and after termination of pregnancy the disease process reverses. The evidence of maternal deaths due to critical illness varies from $1 \%$ to $25 \%$ in developing countries. ${ }^{3}$

According to the type and seriousness of comorbidities and the level of care needed, the patients are shifted to HDU or are further stepped up to ICU or stepped down 
back to HDU before shifting to ward once the patient improves. Intensive care defines four levels of critical care.

- Level 0 - Need can be met through normal ward care

- Level 1 - At risk of deteriorating, needing a higher level of obstetric or those recently shifted from higher levels of care

- Level 2 - Requiring invasive monitoring/ intervention, include support for a single failing organ system (excluding advance respiratory support)

- Level 3 - Requiring advance respiratory support (mechanical ventilation) alone or basic respiratory support along with support of at least one additional organ.

Various haemorrhagic and non-haemorrhagic causes complicate pregnancy and need ICU admissions. Reasons for ICU admission include conditions related to pregnancy (preeclampsia-eclampsia, postpartum hemorrhage, cardiomyopathy, puerperal infection etc.), conditions unrelated to pregnancy (congenital and valvular heart disease, pulmonary hypertension, renal failure etc.) and medical pathologies worsened by pregnancy. ${ }^{4}$ The majority of maternal deaths are caused by haemorrhagic conditions of pregnancy. ${ }^{5}$

Over the past years, as a result of efforts aimed at reducing maternal mortality, there is decrease in mortality due to hypertensive and haemorrhagic complications. Consequently, there has been a relative increase in mortality due to secondary causes such as heart diseases and respiratory diseases. ${ }^{6}$

The aim of this study was to evaluate in more detail the non-haemorrhagic causes of obstetric ICU admissions and to identify and adopt high risk reduction strategies as prime learning objective.

\section{METHODS}

This prospective ongoing study was conducted in multidisciplinary ICU in department of Obstetrics and Gynecology at Sri Guru Ram Das University of Health Sciences, Sri Amritsar from a period of December 2016 to October 2019. The subjects included were admitted from emergency/OPD or shifted from OT to ICU. This study was carried out after acquisition of permission from the ethics committee of the research and technology of this Institution. Total number of patients admitted in obstetric ICU in this period were 50 . Out of these 30 cases were attributed to non-haemorrhagic obstetric causes.

\section{Inclusion criteria}

- Amongst these patients inclusion criteria were ICU admissions during pregnancy or within 42 days of delivery and complete management data available for review.

\section{Exclusion criteria}

- $\quad$ The exclusion criteria were ICU admissions after 42 days of termination of pregnancy or incomplete management data for review.

The extracted data included maternal age, gestational age at the time of admission, parity, mode of delivery, antenatal or postnatal admission, haemorrhagic and nonhaemorrhagic causes of admissions, coexisting medical/surgical problems, final diagnosis, length of ICU stay, interventions required in ICU (monitoring only, non-invasive or invasive ventilator support, inotrope/vasopressor support, cardiovascular support, transfusion of blood or blood products or renal replacement therapy). In addition, demographic characteristics, literacy rate, level of prenatal care, booking or referral status, medical or surgical intervention done before admission in acutely ill patients were also noted.

The subjects were managed by the ICU team, consisting of an anaesthesiologist and critical care fellows. Medical specialists were consulted when needed. This study also evaluated patient outcome, overview of mortality and areas of improvement. Patients were followed till discharged from hospital or till death which ever occurred first. The purpose of review was to adopt more vigorous management strategies in critical care unit.

\section{RESULTS}

Table 1 depicts that out of 50 admissions in ICU, 30 $(60 \%)$ were due to non-haemorrhagic causes and 15 $(50 \%)$ patients among non-haemorrhagic group were due to infective cause and tropical diseases. The concern of the study was raised from this distribution scenario of shift of critical illness to medical morbidities rather than haemorrhagic etiopathology of pregnancy.

Table 2 shows that mean age of patients was $26.23 \pm 4.24$ years and $65.32 \%$ were from rural background. Most of the patients were illiterate $(74.70 \%)$ and were unbooked $(77.3 \%) .56 .8 \%$ of patients did not receive any antenatal care.

Table 3 depicts that majority of the patients (70.01\%) were admitted in $3^{\text {rd }}$ trimester. In first trimester only $6.66 \%$ patients were admitted. $10 \%$ of patients were admitted in postnatal period.

Table 4 shows that other than tropical and infective cases, Hypertensive disorders formed the major bulk for ICU admission for close monitoring after delivery. C. section was done in $33.3 \%$ cases. No intervention was done in $30 \%$ of the patients. 
Table 1: Distribution of cases according to haemorrhagic and non- haemorrhagic reasons for ICU admissions.

\begin{tabular}{|c|c|c|c|}
\hline \multirow{2}{*}{\multicolumn{4}{|c|}{ Non-haemorrhagic (30) Haemorrhagic causes (20) }} \\
\hline & & & \\
\hline Preeclampsia & 3 & $\begin{array}{l}\text { Antepartum } \\
\text { haemorrhage }\end{array}$ & 2 \\
\hline Eclampsia & & $\begin{array}{l}\text { Postpartum } \\
\text { haemorrhage }\end{array}$ & 14 \\
\hline \multirow[t]{2}{*}{ HELLP syndrome } & 1 & Ectopic pregnancy & 2 \\
\hline & & Rupture uterus & 2 \\
\hline \multicolumn{4}{|l|}{ Obstetric sepsis (4) } \\
\hline Puerperal & 2 & & \\
\hline Septic abortion & 2 & & \\
\hline \multicolumn{4}{|l|}{ Medical diseases (6) } \\
\hline Heart disease & 2 & & \\
\hline Severe anaemia & 3 & & \\
\hline Pulmonary embolism & 1 & & \\
\hline \multicolumn{4}{|l|}{ Other causes (12) } \\
\hline Viral hepatitis & 3 & & \\
\hline $\begin{array}{l}\text { Acute fatty liver of } \\
\text { pregnancy }\end{array}$ & 1 & & \\
\hline Dengue fever & 2 & & \\
\hline Swine flu & 3 & & \\
\hline Acute pancreatitis & 1 & & \\
\hline Ludwig angina & 1 & & \\
\hline $\begin{array}{l}\text { Peripartum } \\
\text { cardiomyopathy }\end{array}$ & 1 & & \\
\hline
\end{tabular}

Table 2: Demographic parameters.

\begin{tabular}{|l|l|}
\hline Demographic Parameters & Observations \\
\hline Mean age in years & $26.23 \pm 4.24$ \\
\hline Mean gravidity & $1.76 \pm 0.85$ \\
\hline Rural & $65.32 \%$ \\
\hline Urban & $34.68 \%$ \\
\hline Booked & $22.7 \%$ \\
\hline Un-booked & $77.3 \%$ \\
\hline Literate & $25.30 \%$ \\
\hline Illiterate & $74.70 \%$ \\
\hline Antenatal care given & $43.2 \%$ \\
\hline Not given & $56.8 \%$ \\
\hline
\end{tabular}

Table 3: Distribution of cases according to gestational age.

\begin{tabular}{|l|l|l|}
\hline $\begin{array}{l}\text { Duration of } \\
\text { pregnancy }\end{array}$ & Numbers $(\mathbf{n}=\mathbf{3 0})$ & $\begin{array}{l}\text { In } \\
\text { percentage }\end{array}$ \\
\hline $1^{\text {st }}$ trimester & 2 & $6.66 \%$ \\
\hline $2^{\text {nd }}$ trimester & 4 & $13.33 \%$ \\
\hline $3^{\text {rd }}$ trimester & 21 & $70.01 \%$ \\
\hline Postpartum & 3 & $10 \%$ \\
\hline
\end{tabular}

Table 5 depicts that mechanical ventilation was done in $19(63.3 \%)$ cases. Inotropes were given in $18(60 \%)$ cases. Anticonvulsants were given in $23.3 \%$ cases of hypertensive disorder. In 3 patients $(10 \%)$ who had renal failure, dialysis was required.

Table 4: Distribution of cases according to diagnosis versus gestational age and intervention done before ICU admission.

\begin{tabular}{|c|c|c|c|}
\hline Indication & $\begin{array}{l}\text { Gestational } \\
\text { age }\end{array}$ & Intervention & $\begin{array}{l}\text { No. of } \\
\text { cases } \\
(\mathrm{N}=30)\end{array}$ \\
\hline \multirow{3}{*}{ Eclampsia } & $\simeq 34$ weeks & LSCS & 2 \\
\hline & ב 36 weeks & LSCS & 2 \\
\hline & Term & LSCS & 1 \\
\hline \multirow{2}{*}{ Preeclampsia } & $\simeq 34$ weeks & LSCS & 2 \\
\hline & $\simeq 26$ weeks & Hysterotomy & 1 \\
\hline \multirow{3}{*}{ Septic shock } & $\begin{array}{l}\text { Post } \\
\text { abortion }\end{array}$ & Laparotomy & 2 \\
\hline & Puerperium & $\begin{array}{l}\text { ICU } \\
\text { management }\end{array}$ & 1 \\
\hline & - & Laparotomy & 1 \\
\hline \multirow{2}{*}{$\begin{array}{l}\text { RHD with } \\
\text { mitral stenosis }\end{array}$} & $\simeq 36$ weeks & $\begin{array}{l}\text { Vaginal } \\
\text { delivery }\end{array}$ & 1 \\
\hline & $\simeq 34$ weeks & LSCS & 1 \\
\hline \multirow{3}{*}{$\begin{array}{l}\text { Severe anemia } \\
\text { with dyspnoea }\end{array}$} & $\simeq 33$ weeks & $\begin{array}{l}\text { Vaginal } \\
\text { delivery }\end{array}$ & 1 \\
\hline & $\simeq 36$ weeks & $\begin{array}{l}\text { Vaginal } \\
\text { delivery }\end{array}$ & 1 \\
\hline & Term & $\begin{array}{l}\text { Vaginal } \\
\text { delivery }\end{array}$ & 1 \\
\hline $\begin{array}{l}\text { Pulmonary } \\
\text { embolism }\end{array}$ & Puerperium & $\begin{array}{l}\text { ICU } \\
\text { management }\end{array}$ & 1 \\
\hline \multirow{3}{*}{ Viral hepatitis } & $\simeq 30$ weeks & Undelivered & 1 \\
\hline & $\simeq 32$ weeks & Undelivered & 1 \\
\hline & $\simeq 36$ weeks & $\begin{array}{l}\text { Vaginal } \\
\text { delivery }\end{array}$ & 1 \\
\hline $\begin{array}{l}\text { Acute fatty } \\
\text { liver }\end{array}$ & Term & $\begin{array}{l}\text { Vaginal } \\
\text { delivery }\end{array}$ & 1 \\
\hline \multirow{2}{*}{ Dengue fever } & $\simeq 32$ weeks & Undelivered & 1 \\
\hline & $\simeq 24$ weeks & Undelivered & 1 \\
\hline \multirow{3}{*}{ Swine flu } & $\simeq 25$ weeks & Undelivered & 1 \\
\hline & $\simeq 32$ weeks & Undelivered & 1 \\
\hline & $\simeq 38$ weeks & $\begin{array}{l}\text { Vaginal } \\
\text { delivery }\end{array}$ & 1 \\
\hline Acute pancreatitis & $\simeq 26$ weeks & Undelivered & 1 \\
\hline Ludwig angina & Term & LSCS & 1 \\
\hline $\begin{array}{l}\text { Peripartum } \\
\text { cardiomyopathy }\end{array}$ & $\simeq 36$ weeks & LSCS & 1 \\
\hline
\end{tabular}

Table 6 shows that among the non-survivors $40 \%$ cases succumbed within 24 hours and 30\% died after 72 hours. Maximum mortalities occurred within 24 hours as all were referred to the hospital (being a tertiary institute) in a critical condition.

The explanation for early deaths is their critical irreversible terminal stage at admission and late deaths were being due to poor response to intensive treatment. 
Table 5: ICU interventions.

\begin{tabular}{|lll|}
\hline ICU intervention & No. of cases & Percentage \\
\hline Mechanical ventilation & 19 & $63.3 \%$ \\
\hline Blood products & 10 & $33.3 \%$ \\
\hline Inotropes & 18 & $60 \%$ \\
\hline Dialysis & 3 & $10 \%$ \\
\hline Anti-convulsant & 7 & $23.4 \%$ \\
\hline Antihypertensive & 9 & $30 \%$ \\
\hline
\end{tabular}

Table 6: ICU stay in survivors and non-survivors.

\begin{tabular}{|lll|}
\hline $\begin{array}{l}\text { Duration of ICU } \\
\text { stay }\end{array}$ & $\begin{array}{l}\text { Survivors } \\
(\mathbf{n}=\mathbf{2 0})\end{array}$ & $\begin{array}{l}\text { Non-survivors } \\
(\mathbf{n}=\mathbf{1 0})\end{array}$ \\
\hline$<24$ hours & 0 & 4 \\
\hline $25-48$ hours & 1 & 2 \\
\hline $49-72$ hours & 9 & 1 \\
\hline$>72$ hours & 10 & 3 \\
\hline
\end{tabular}

Table 7 depicts that among non-survivors, in 30\% of patients no intervention was done before shifting the patient to ICU. Most common cause of death in present study was respiratory failure in $40 \%$ cases and Multiorgan failure and congestive cardiac failure each contributed to $30 \%$ of mortality.

Table 8 shows that optimal antenatal management should be done and risk factors like hypertensive disorders, severe anemia should be identified and managed at appropriate time. There is change in trend in cause of maternal mortality as tropical diseases like dengue fever, swine flu, viral hepatitis is emerging as a leading cause of maternal morbidity requiring ICU admission and management. In these cases, no risk factor could be identified in routine antenatal surveillance and no opportunity was available for optimization. Early admission, timely blood transfusion helps in managing critically ill patients and thus decreases the maternal mortality.

Table 7: Distribution of cases according to cause of maternal mortality versus obstetrical interventions done among non-survivors.

\begin{tabular}{|llll|}
\hline Pre ICU admission diagnosis & Interventions done before ICU shifting & Cause Of Mortality & $\mathbf{N}=\mathbf{1 0}$ \\
\hline Swine flu & Nil & Respiratory failure & 3 \\
\hline Peripartum cardiomyopathy & LSCS & Congestive cardiac failure & 1 \\
\hline Acute fatty liver & LSCS & Multiorgan failure & 1 \\
\hline Septic shock & Laparotomy & Multiorgan failure & 1 \\
\hline RHD with mitral stenosis & Nil & Congestive cardiac failure & 1 \\
\hline Anaemia & Vaginal delivery & Congestive cardiac failure & 1 \\
\hline Pulmonary embolism & Nil & Respiratory failure & 1 \\
\hline Eclampsia & LSCS & Multiorgan failure & 1 \\
\hline
\end{tabular}

Table 8: Distribution of cases according to the area of improvement.

\begin{tabular}{|l|l|}
\hline Area & Results obtained \\
\hline Anaemia correction & 3 \\
\hline Early admission & 5 \\
\hline High risk stratification & 8 \\
\hline Contraceptive advice & 9 \\
\hline Blood arrangements & 10 \\
\hline No optimization opportunity & 10 \\
\hline
\end{tabular}

\section{DISCUSSION}

Obstetric medicine is unique and complicated. Obstetric emergencies are a challenge to the obstetrician because of altered physiology of pregnancy, especially in second half. There is rapid deterioration of maternal and fetal condition in case of a complication and simultaneous management of two lives with different physiologies has to be done. The threshold of an insult required for ICU admission is low in obstetric patients as compared to nonpregnant population.

In this study mean age of patients requiring ICU admission was $26.23 \pm 4.24$ years. It is comparable to study conducted by Ghike $\mathrm{S}$ et al, where mean age was 26.05 years. $^{7}$ Most of the patients in this study were illiterate $(74.70 \%)$ and were un-booked $(77.3 \%)$. This reflects that there are more ICU admissions due to low socioeconomic status, poor antenatal care and delay in timely referral to tertiary institutes. In a study conducted by Gupta $\mathrm{S}$ et al, $54.16 \%$ patients admitted in ICU were illiterate. $^{8}$ There is need to establish critical units in peripheral areas with trained junior doctors and nurses who are familiar with obstetric complications and can perform primary evaluation and intervention before referring the patient to tertiary centre.

In this study among $50 \mathrm{ICU}$ admissions $30(60 \%)$ patients were admitted due to non-hemorrhagic causes. In a study conducted by Mowafy AH et al, it was found that $34.12 \%$ cases were that of non-hemorrhagic cause. ${ }^{9}$ Among the 
patients in non-hemorrhagic group in this study $26.6 \%$ of cases were that of hypertensive disorders. The other conditions were sepsis $(13.33 \%)$, heart disease $(6.66 \%)$ and severe anemia $(10 \%)$. In a study conducted by Rathod AT et al, $28.88 \%$ of ICU admissions were due to hypertensive disorder of pregnancy. ${ }^{10}$ The other conditions were severe anemia $(14.37 \%)$, heart disease $(12.15 \%)$ and sepsis $(7.97 \%)$ which is comparable to this study.

In present study dengue fever was seen in $(6.6 \%)$ of cases which is comparable to study conducted by Sharma $\mathrm{S}$ et al, $(6.8 \%){ }^{11}$ There were $(10 \%)$ cases of viral hepatitis and $(10 \%)$ were that of Swine flu which are comparable to study carried out by Ghike S et al. ${ }^{7}$

In current study $70.01 \%$ patients were admitted in ICU in 3rd trimester of pregnancy which is comparable to the study conducted by Gupta S et al, where mean gestational age of ICU admission was from 31 to 36 weeks. ${ }^{8}$ It may be due to altered physiology which affects mainly second half of the pregnancy. This could be a reason for the medical conditions getting worsened and making the patient compromised. In first trimester the causes of maternal morbidity like septic abortion are related to interventional problems

Among the patients admitted in ICU due to nonhemorrhagic causes, $(23.33 \%)$ underwent vaginal delivery and in $(33.33 \%)$ cases caesarean delivery was done. It is comparable to the findings of Sheikh $\mathrm{S}$ et al, (vaginal delivery $37.4 \%$, caesarean delivery $49.4 \%$ ). ${ }^{12}$ Caesarean delivery in presence of medical comorbidities can be a potential risk factor for ICU admission. In this study laparotomy and hysterotomy was done in $10 \%$ and $3.3 \%$ of patients respectively. One patient at 26 weeks was admitted with concealed accidental hemorrhage and required urgent hysterotomy. Laparotomy was required in a haemodynamic unstable patient admitted with septic abortion with perforation after dilatation and curettage. In other patient of puerperal sepsis laparotomy was done and pelvic abscess was drained.

In present study $63.3 \%$ of the patients required intubation and mechanical ventilation which is comparable to study carried out by Gupta S et al, and Sheikh S et al, where intubation was required in $70.83 \%$ and $71 \%$ respectively. ${ }^{8,12}$ In this study blood transfusion was required in $33.3 \%$ cases and dialysis was done in $10 \%$ of patients which is comparable to study conducted by Zwart JJ et al. ${ }^{13}$ In present study total number of maternal deaths were 10 which accounted for $33.3 \%$ of the total patients admitted in ICU due to non-hemorrhagic causes. The commonest cause of maternal mortality in this group was respiratory failure $(40 \%)$ followed by congestive heart failure and multiorgan failure seen in $(30 \%)$ of patients each. However, in study conducted by Vasquez DN et al, multi-organ dysfunction syndrome contributed to $(44 \%)$ mortality irrespective of the primary disease. ${ }^{14}$ Multi-organ failure commonly occurs in pregnancy as end result. ${ }^{5}$ To achieve the optimal maternal and fetal outcome, a multidisciplinary team consisting of obstetrician, intensivist and a clinical pharmacologist is required.

\section{CONCLUSION}

This study underlines the unique characteristics of obstetric patients who were critically ill due to nonhaemorrhagic causes. Hypertensive disorders of pregnancy, tropical diseases like Swine flu, viral hepatitis, dengue fever etc. were the common reasons for ICU admission.

The mindset of an obstetrician is only to handle and be vigilant for haemorrhagic causes while non-haemorrhagic causes other than PIH are like acute emergency situations (undiagnosed or diagnosed earlier but not optimized) where the patient is compromised and mortality quotient is high, like severe anemia, heart disease, dengue and swine flu subjects.

To get awareness for medical morbidities in obstetrical subjects periodical updating of current problems is needed. A multidisciplinary approach is ideal to handle non haemorrhagic situations especially related to heart disease and tropical diseases. Review of ICU admissions and periodical audit can improve management of morbidities as well as reduce the maternal mortalities.

\section{ACKNOWLEDGMENTS}

Authors would like to thank department of obstetrics and gynecology of SGRDIMSR, Amritsar.

Funding: No funding sources

Conflict of interest: None declared

Ethical approval: The study was approved by the Institutional Ethics Committee

\section{REFERENCES}

1. Bajwa SS, Kaur J. Critical care challenges in obstetrics: An acute need for dedicated and coordinated teamwork. Anesth Essays Res. 2014;8:267-9.

2. Price LC, German S, Wyncoll D, Nelson Piercy C. Management of critically ill obstetric patient. Obstet Gynaecol Reprod Med. 2009;19:350-8.

3. Ramechandra PB, Navade MH, Rao SV, Nagarathna G. Evaluation of obstetric admissions to intensive care unit of tertiary referral center in coastal India. Indian J Crit Care Med. 2013;17(1):34-7.

4. Snelgrone JW. Postpartum haemorrhage in developing word a review of clinical management strategies. Mcgill J Med. 2009;12(2):61.

5. Karnad DR, Lapsia V, Krishnan A, Salvi VS. Prognostic factors in obstetric patients admitted to an Indian intensive care unit. Crit Care Med. 2004;32(6):1294-9. 
6. Mahutte NG, Murphy-Kaulbeck L, Le Q, Solomon J, Benjamin A, Boyd ME. Obstetric admission to the intensive care unit. Obstet Gynecol. 1999;94(2):2636.

7. Ghike S, Asegaonkar P. Why obstetric patients are admitted to intensive care unit? A retrospective study. J South Asian Feder Obst. Gynae. 2012;4(2):90-2.

8. Gupta S, Naithani U, Doshi V, Bhargava V, Vijay BS. Obstetric critical care: a prospective analysis of clinical characteristics, predictability, and fetomaternal outcome in a new dedicated obstetric intensive care unit. Indian J Anaesth. 2011;55(2):146-53.

9. Mowafy AH, Mashhour KS. Clinical characteristics and outcomes of obstetric patients requiring ICU admission. Med J Cairo Univ. 2010;78(2):835-44.

10. Rathod AT, Malini KV. Study of obstetric admissions to the Intensive care unit of a Tertiary Care Hospital. J Obstet Gynaecol India. 2016;66(1):12-7.

11. Sharma S, Garg S, Taneja A, Puri S, Course and outcome of critically ill obstetric patients in ICUs of a tertiary care hospital in north India. Indian $\mathrm{J}$ Mat Child Health. 2010;12(1):1-11.

12. Sheikh S, Najma Bano Sheikh NB, Abassi R, Balouch R. Obstetric admission to the intensive care unit: a one-year review. Med Chan. 2013;19(3):5963.

13. Zwart JJ, Dupuis JR, Richters A, Ory F, van Roosmalen J. Obstetric intensive care unit admission: a 2-year nationwide population-based cohort study. Intensive Care Med. 2010;36(2):25663.

14. Vasquez DN, Estenssoro E, Canales HS, Reina R, Saenz MG, Das Neves AV, et al. Clinical characteristics and outcomes of obstetric patients requiring ICU admission. Chest. 2007;131(3):71824.

Cite this article as: Kamal $\mathrm{P}$, Kaur S, Kaur H, Nagpal M. Non-haemorrhagic causes of obstetrical intensive care unit admissions in tertiary care setting. Int J Reprod Contracept Obstet Gynecol 2020;9:1392-7. 